Vol. 2, No. 06; 2019

ISSN: 2581-4664

\title{
REVIEW OF ISLAMIC ACCOUNTING ON MURĀBAHAH FINANCING ACCOUNTING ON ISLAMIC BANKING (STUDY IN BANK SYARIAH MANDIRI OF BANDA ACEH)
}

\author{
Mardiaton*, Aliamin, Muhammad Arfan \\ Faculty of Economics and Business, Universitas Syiah Kuala, Banda Aceh, Indonesia \\ http://doi.org/10.35409/IJBMER.2019.2422
}

\begin{abstract}
The objective of this study is to analyze and determine the murābahah financing system carried out at Bank Syariah Mandiri (BSM) of Banda Aceh in accordance with Islamic accounting reviews. This is a descriptive research with primary and secondary data directly obtained from research site, and variety of literatures respectively. The results of the study which was carried out at BSM, indicate that accounting for murābahah transactions has not been fully utilized in accordance with (Penyataan Standar Akuntansi Keuangan (PSAK) (Statement of Financial Accounting Standards)\} PSAK Number: 102. Similarly, some transactions cannot also be recorded because the bank expects the customer to purchase goods by providing a certain amount of funds. The recognition of the murābahah profit still uses the annuity method and the inventory of its assets has never been presented in the statement of financial position due to its unavailability by the bank.
\end{abstract}

Keyword: Islamic Accounting, Murābahah Financing, PSAK Number 102, Bank Syariah Mandiri.

\section{INTRODUCTION}

One of the financing contract (agreements) in Islamic banking based on muamalah is the muräbahah contract. This is the sale and purchase of goods (assets) by expressing its cost (origin) to the buyer along with the profit (margin) agreed by both parties. Murābahah is a contract with the intention of obtaining profits based on buying and selling transactions worth the value. It is contract with the intention of obtaining profits based on the terms, and stipulated conditions (Dewi \& Wirdyaningsih, 2007).

As one of the economic activities, its users must obey the implementation of murābahah accounting. In Indonesia, this is stated in the PSAK Number 102. Accounting helps interested parties to obtain information, conditions and economic performance of a company from financial statements. It displays the margin associated with murābahah income as reported by BSM in the income statement and its margin on the balance sheet (Bank Syariah Mandiri, 2018). In the banking world, its contract is the most popular in Indonesia. The Islamic banking statistics illustrates that the transaction value or muräbahah contract is in the top rank of 106.779 Billion Rupiahs, musyarakah contract of 36.715 Billion Rupiahs, and mudharabah contract of 13.364 


\section{International Journal of Business Management and Economic Review}

Vol. 2, No. 06; 2019

ISSN: 2581-4664

Billion Rupiahs (Bank Indonesia, 2013).

The Dewan Standar Akuntansi Syariah \{(DSAS) (Islamic Accounting Standards Board)\} is in line with the growth of muräbahahcontract-based Islamic banking products. The Indonesian accountant association calls on every company/entity that conducts transaction to refer to and comply with PSAK Number: 102. However, this has not been fully realized as indicated by the number of financial institutions that violate these rules and conditions. Some previous studies revealed that in the murābahah contract, sellers still make mistakes its application. Islamic banking products with the PLS method (profit and loss sharing) or revenue sharing should be better than others, because the financing accelerates growth, improve welfare, and help empower the economy of the people (Rahmanti, 2013).

Rusydi and Nasir (2009) conducted research on its applicationat BSM of Makassar. The results of these studies indicated that $B S M$ has not fully implemented PSAK Number: 102, due to their operating strategy which only regulates sales, while PSAK Number: 102 arranges sales and purchases. Wardi and Putri (2011), also conducted a study on its application at Bank Muamalat of Pekanbaru. The results of the analysis showed that it has not implemented the rules or standards. This can be seen from the determination of margins, profit sharing and recognition of itsassets for buyer accounting which are not properly applied as stipulated in PSAK Number: 102. Habibah and Nikmah (2016), also examined the comparison between the adoption of accounting murābahahat BMT in Pati Regency. The results of this research indicated that the profit/loss report did not reveal the cost of receivables and the balance sheet did not display the reserve value. This was as a result of the absence of records.

Some researchers also stated that the seller made a mistake in applying PSAK Numbetr: 102 with regards to the murābahah contract (Menne, et al., 2016; Hariyanto, 2015) and only applied biased rules (Yusuf, 2013). The application of the muräbahah contract to Islamic banking is not yet in accordance with Islamic legal norms (Azkanar, 2016; Rahmanti, 2013; Rahmawati et al., 2009; Imama, 2014). A few number of research also showed the need for changes and additional policies in murābahah contract (Wulandari et al., 2016; Maryanti et al., 2016). Furthermore, some findings indicated the suitability of the implementation between muräbahah accounting, PSAK and Islamic law (Luayyi, 2005; Hanum, 2014; Nasir and Sululing, 2015; Hasmitha and Ja'far, 2012; and Kholis, 2007). In addition, Buziek's (2011) stated that there are similarities in the implementation of PSAK Number: 102 in Islamic banking system, except for tax regulations due to the differences associated with the regulations .

Ideally, $B S M$ should have assets and then make a sale and purchase contract. However, customers only receives "receipts" when the $B S M$ represents their asset purchase. Furthermore, $B S M$ never showed murabah assets, because it is inadequate, rather it represented the acquisition of assets on behalf of the bank through the supplier's customers. In its implementation, inventory always has a zero balance therefore, it is not recorded in the financial statements. Basically, the bank has provided all recording systems, however, not all is recorded due to the purchase of assets using a wakalah contract (the purchase of assets is represented by the customer through the provision of a power of attorney from the bank to the customer). Furthermore, its assets acquisition such as inventory, down-payments by customers, discounts when purchasing murābahah assets and recognizing damages before handing it over to customers should be properly detailed (interview with informant I).

In addition, the implementation of its transactions is not too different from the practice of credit 


\section{International Journal of Business Management and Economic Review}

Vol. 2, No. 06; 2019

ISSN: 2581-4664

at conventional banks which provide cash loans to customers according to the price of their commodities. Customers must pay a loan (plus margin) to the bank as agreed at the beginning of the contract (interview with informant II). To enhance professional performance, banks must make changes to produce financial reports capable of facilitating the decision-making process for Islamic banking in the future. The mismatch between the implementation of murābahah accounting financing with the rules of Islamic law and PSAK (statement of financial accounting standards) Number: 102 must also be improved. Therefore, this study examines murābahah financing accounting at Bank Syariah Mandiri (BSM) of Banda Aceh, which uses the principle of profit or margin.

\section{LITERATURE REVIEW}

\section{Muräbahah Financing}

Law Number:10 of 1998 article 1 paragraph 12 states that: "Islamic-based financing is the provision of money or equivalent claims based on an agreement between the bank and another party. The financed party is expected to return the money or bill after a certain period of time with a reward or profit share".

Sabiq (1988: 83) defines murābahah as buying and selling goods with its cost (origin) and profits known to both parties. According to Shiddieqy (1997: 353), murābahah is the sale and purchase of goods by taking certain advantages. Italso means financing contracts using the method of deferred sale and purchase transactions as well as installments. Muräbahah is an contract of sale and purchase in accordance with Islamic principles and legal rules that apply in economics (Muhammad, 2000: 22).

Based on previusly described, it can be understood that, muräbahah is an contract that applies between the seller and buyer, where the seller shows the basic price and the profit agreed upon between both parties.Muräbahah transactions that occur in the trading industry must meet the determined conditions (Dimyauddin, 2010: 111), which are: (i) the contractor, between both are required to be competent to the law, (ii) the existence of objects that are traded and not usury goods, (iii) the price arising from buying and selling, clearly explained the amount and unit of currency and ) the handover of goods (ijabqabul/agreement) between the seller and the buyer.

The terms and conditions in the transaction are: (1) parties that have contracts, such as legal and voluntary, under pressure, (2) traded objects excluding those that are prohibited, must be beneficial, with full ownership rights of parties that have contract, and specifications, having the same values when received by the buyer, (3) contract: there is tranquility between the specification of goods, and agreed prices, which does not contain doubtful clauses about the validity of the transaction (ambiguous) on things or future events with unlimited time. For instance, this will be mine again in the next 12 months after selling it to you (Rifqi, 2008: 150). In addition, the National Islamic Council stated that the General Provisions of Murābahah in financial institutions and itsprovision to Customers contained in Fatwa Number: 04 / DSN-MUI / IV / 2000.

\section{Islamic Accounting}

According to Harahap (2007: 371), Islamic accounting is a system, concept, and banking technique used to help entities (companies) with the aim of keeping the operational functions of a bank and in accordance with Islamic principles. It protects and safeguards interested parties (stakeholders) both internally and externally, and make these entities able to achieve the ultimate 


\section{International Journal of Business Management and Economic Review}

Vol. 2, No. 06; 2019

ISSN: 2581-4664

goals.

Muhammad (2002: 14) stated that Islamic accounting is an accounting system adopted from philosophical developments in the principles and norms of Islamic law. Therefore, the technique of recording, classifying, recapitulating, and analyzing financial data carried out in accordance with the provisions and principles of Islamic law.

\section{Murābahah Transaction Recording Technique}

Related to murābahah contract transactions in Islamic financial institutions, the recording techniques that can be performed by the bank are as follows:

1. Recognition of down-payment is not recorded during negotiations, because it does not have an influence on financial statements. However, there are three alternative ways to acknowledge down-payment as follows, 1) debiting those submitted by the customer, 2) blocking the customer's account in accordance with the agreement, and 3) the prompting the customer to pay it directly to the supplier (Yaya et al., 2009).

An alternative method used to debit down-payment directly from customer's account is by deducting the amount from their savings. Down-payments through blocking the clients accounts are carried out by debiting and crediting murābahah receivables. However, if the customer decides to hold and pay to the supplier, the recording is carried out by debiting the wakalah receivables and crediting their account. When the consumer hands over the goods, the banksdebits the muräbahah inventory and credit the wakalah receivables (Yaya et al., 2009).

2. The purchase of goods (assets) can be conducted in two ways, which comprises of (i) the bank buys goods from the supplier and (ii) goods are purchased on behalf of the bank by representing purchases to the customer through a wakalah contract. The goods purchased in cash from the supplier are recorded by debiting the inventory of the muräbahah asset and crediting the supplier's cash/account. Furthermore, the banks can also purchase goods from suppliers on credit. Recording settlement of bank loans to suppliers can be done by debiting debts to suppliers and crediting supplier's cash / accounts (Yaya et al., 2009).However, if the murābahah contractis not carried out, the buyer can cancel the purchase of the goods and take back their down-payment from the bank, after deducting some murābahah contract fees in accordance with paragraph 30 (IAI, 2013). Down-payment returns are recorded as debit, while operating income and cash are credited (Yaya et al., 2009).

3. When agreeing to the murābahah contract, the bank sells its assets to the customer. paragraph 22 states that murābahah receivables are recognized in the amount of acquisition of its assets plus agreed profits. Recording related to the transaction can be conducted by debiting murābahahreceivables, its inventory assets and suspending margin credit (Yaya et al., 2009).

4. Down-payment as part of settlement of murābahah receivables is recorded in accordance with certain methods before the contract is agreed as stated in paragraph 30. Recording downpayment by debiting customer accounts and acknowledging it as part of settlement of murābahah receivables is conducted by debiting those provided by customers (Yaya et al., 2009).

5. At the time of realization of the murābahah financing budget, its receivables granted to customers are recognized in the amount of acquisition of assets plus agreed benefits based on 


\section{International Journal of Business Management and Economic Review}

Vol. 2, No. 06; 2019

ISSN: 2581-4664

paragraph 22. The recording is carried out by debiting the receivables and crediting its assets and deferred margin (Yaya et al., 2009).

6. When the murābahah contract is agreed upon, the bank charges several types of fees to the customer, therefore, recording is carried out by debiting the customer's account and crediting administrative, stamp, notary and insurance costs (Yaya et al., 2009).

7. Recognition of margin murābahah income consists of three alternatives, 1) the margin at the time of delivery of assets to customers, 2) the amount of cash that the bank collects from murābahah receivables, and 3) recognizing the margin at the time of receivables all of these have been successfully billed (IAI, 2013)

Recognition of margin murābahah at the time of asset hand-over can be recorded by debiting its receivables and its assets inventory by crediting the margin income. When the installment payment is made by the customer, with the cash/account debited and the murābahah receivables credited. Furthermore, when the last installment payment by the customer, is deferred, the murābahah margin can be debited with itsreceivables and margin income credited(Yaya et al., 2009).

8. The bank records customer installment payments on the due date by debiting their cash/accounts and deferred murābahah margins, while its accounts and margin revenues are credited (Yaya et al., 2009).

9. Assuming the customer fails to pay the installments on the due date, and the bank tolerates the delay and does not impose a fine, the recording is carried out by debiting the receivables, deferred margin, customer cash/ account, and accrual income (accounts receivable) While the murābahah receivables, margin accrual income, due-murabahah payables and margin income are credited. (Yaya et al., 2009).

10. The customer pays part of the installments at the due date, and some after without being fined for reasons acceptable by the bank. The recording is done by debiting the muräbahah receivables due and the deferred margin. While the accounts, margin income, and accrual margin income are credited. However, if the customer pays a shortfall of the remaining installment, then the recording can be carried out by debiting their cash/account and the murabahah-accrual margin income, while the receivables due and margin income are credited (Yaya et al., 2009).

11. Assuming the customer cannot pay the installments on the due date, and pays after (even though he is able to pay), the bank imposes a fine. The recording is conducted by debiting itsdue receivables, deferred margins, customer cash/accounts, accrual income, and customer accounts. The virtue funds can be taken from $10 \%$ of the total accrual margin (Yaya et al., 2009).

12. On the assumption that the customer repays all murābahah receivables (early settlement) on the date before maturity, the bank provides a deduction to the customer. These are of two types namely deductions at settlement and after settlement. The recording is conducted by debiting customer cash/accounts, deferred murābahah margins,. While crediting its receivables and margin income. The deduction after settlement can be carried out by debiting the customer's cash/account, the deferred murābahah margin, and its income. While 


\section{International Journal of Business Management and Economic Review}

Vol. 2, No. 06; 2019

ISSN: 2581-4664

themuräbahah accounts, its margin income, and customer cash/accounts are credited (Yaya et al., 2009)

\section{RESEARCH METHOD}

This study aims to analyze and determine the murābahah financing system and the suitability between the Bank Syariah Mandiri of Banda Aceh and Islamic accounting. This is a descriptive analysis study with primary data obtained directly from the place of research while the secondary is from various literatures. This method is generally carried out in case study research using a qualitative approach. It also utilizes a cross-sectional time horizon, carried out with one data collection in a specified timeframe within the research (Indriantoro \& Supomo, 2002: 95).

Data was also obtained through documentation and interviews/questionnaires from Bank Syariah Mandiri of Banda Aceh. The data were analyzed to acquire an accurate, detailed, systematic, and comprehensive description of various matters relating to the implementation of murābahah finance accounting at Bank Syariah Mandiri of Banda Aceh.

\section{Analysis Method}

This research uses the descriptive analysis method by identifying the implementation of murābahah financing accounting at Bank Syariah Mandiri, Banda Aceh. Furthermore, an analysis is conducted to assess the suitability between the implementation of accounting carried out by the bank and the $P S A K$, or by drawing conclusions from data analysis and knowing the suitability of the theory and practice of implementing accounting in Islamic banks. The process of data analysis in this study can be carried out through data reduction, data display, and conclusions or verification.

After collecting data, the researcher reduced its amount by concluding, selecting important things, focusing on the main ideas, looking for themes and patterns, and eliminating unnecessary items. Furthermore, data was presented by looking at the overall picture or certain parts. At the conclusion or verification stage, the data obtained were explained and concluded by looking for similarities, differences, and relationships between theory and existing data (Siyoto \& Sodik, 2015:120).

\section{RESULTS AND DISCUSSION}

The Implementation of Accounting for Murābahah Financing in Bank Syariah Mandiri Based on PSAK No. 102

Based on the distribution of murābahah financing, the $B S M$ provides loan in the form of capital loans and inventory. Funding is provided in the form of cash funds deposited to the customer's account for the purchase of goods or assets. In this case, $B S M$ gives authority to customers to purchase goods to suppliers on behalf of the bank (interview with informant II). The following is the recording used by $B S M$ with respect td to the murābahah financing transaction (interview with informant III):

1. During negotiations with customers, it did not conduct down-payment recording, rather it was recognized as part of the purchase of goods or assets in the amount received. The transaction is in accordance with $B S M$, because it recognizes down-payment as part of 


\section{International Journal of Business Management and Economic Review}

Vol. 2, No. 06; 2019

ISSN: 2581-4664

settlement of murābahah contract as stated. However, in this case, it does not record because the customer holds and makes down-payment directly to suppliers.

2. $B S M$ does not record during the purchase of assets, either directly, in cash, or credit to suppliers because it has been represented to the customer. This shows that accounting for the acquisition of murābahah assets at BSM is not in accordance with PSAK Number: 102 because the bank cannot recognize assets as inventories. In this case, BSM should be able to purchase goods directly from suppliers and recorded when acquiring murābahah assets.

3. $B S M$ does not record its sale of murābahah assets to customers because the purchase of goods has been represented. This transaction shows that accounting for the sale of murābahah assets has not been in accordance with the characteristics listed due to the $B S M$ not having assets to resell to customers. In reality, suppliers never give assets to $B S M$ which was resold by the customer. $B S M$ should be able to make direct purchases to suppliers and resell to customers as stipulated in (IAI, 2013).

4. There is no down-payment record, but it is still recognized as part of the settlement of murābahah, due to the fact that the purchase of goods has been presented to the customer. The transaction shows that BSM imposes down-payment on customers if they make a murābahah agreement, but it does not record it because the purchase of goods is represented by the buyer. In its implementation, the down-payment is held and paid by the customer to the supplier with its provisions regulated in paragraph 30 of the rule. The acknowledgment of down-payment can be conducted in accordance with certain methods before the murābahah contractis agreed (IAI, 2013).

5. When the muräbahah financing is disbursed, the customer is given a number of funds to buy the desired item or asset. The recording by BSM related to the transaction is carried out by debiting the murābahah receivables and crediting the customer's account. With regards to the transaction, the recording carried out by BSM was not in accordance with paragraph 22, because its receivables are not recognized at the cost of the asset, but the amount of cash loan given along with the agreed profit (IAI, 2013).

6. BSM charges fees related to the murābahah agreement, such as administration, stamp, notary, and insurance costs fees to customers. These costs are not taken from the funds but from those deposited by the customer before the disbursement date. Recording is conducted by debiting the customer's account and crediting administrative, stamp, notary and insurance costs. Costs related to contracts are not regulated in the statement of financial accounting standards .

7. BSM records installments at the due date by debiting cash / customer accounts, deferred margins incomes and crediting accounts. The transaction shows that BSM received installment payments from customers. The bank states that the recognition of murābahah profit in real terms is recognized when its receivables are fully collected (IAI, 2013). Recognition of murābahah benefits by annuity which states that can be conducted proportionally. However, its profit is regulated in paragraphs 23 .

8. $B S M$ does not impose a fine on installment payments made after the due date due to the provision of an acceptable reason by the customer. For example, they pay installments for 


\section{International Journal of Business Management and Economic Review}

Vol. 2, No. 06; 2019

ISSN: 2581-4664

March $10-20,2017$. The transaction recording is carried out by debiting the customer's cash/account, the deferred margin income and by crediting the receivables. Related to the transaction, $B S M$ records every installment payment and recognition of the profits paid by the customer every month. The transaction is in accordance with paragraph 23. BSM does not record on the due date, but when the customer pays the installments.

9. The Customer pays a portion of the installments at the due date and partly afterwards. Recording related to the transaction is carried out by debiting the customer's account and crediting the social penalty funds, receivables and margin income. Based on the transaction, $B S M$ does not record at the due date, but is conducted when the customer pays installments every month. With regards to the above transaction, $B S M$ has recorded installment payments and recognition of murābahah benefits in accordance with paragraph 23 and imposition of fines with respect to paragraph 29 (IAI, 2013). Postponement of payment is also regulated in DSN-MUI Number: 04 / DSN-MUI / IV / 2000.

10. When $B S M$ gives a deduction on settlement of murābahah receivables to customers, the bank uses a deduction method at the time of settlement, by reducing the receivables and profits murābahah. The recording is carried out by debiting the customer's money and crediting murābahah accounts (basic and margin deducted). The transaction is in accordance with paragraph 27 (a) due to the fact that the BSM provides deductions during settlement (IAI, 2013).

\section{Recognition and Measurement of Muräbahah Transactions}

$B S M$ cannot recognize and measure murābahah transactions. This is indicated by several transactions which cannot be recognized such as the acquisition of assets. These are not obtained from suppliers but by the customer, therefore, the measurement of murābahah assets after acquisition is not conducted, either on bound or unbound orders as contained in paragraphs 1819 (IAI, 2013).

Deduction of asset purchases cannot be recognized from the acquisition cost of murābahah valuables, liabilities to buyers, additional profits, and other operating income contained in paragraph 20 owing to the fact that the purchase of assets has been directly represented to the customer. Furthermore, when the contracts are made, the BSM recognizes the muräbahah receivables in the amount of the loan issued to the customer along with the agreed revenue. Profit recognition is carried out using the annuity method, and not the proportional method as stated in paragraph 23-25 (IAI, 2013).

In connection with the deduction of settlement on murābahah receivables to customers who pay on time or earlier from the agreed time, $B S M$ recognizes it as a deduction of profits issued at the time of settlement.The seller reduces the receivables and benefits as contained in paragraphs 2628. With regard to fines, if the customer neglects his obligations in accordance with the agreement, and fines received are part of the virtue fund, not bank income as contained in paragraph 29 (IAI, 2013). Elimination of fines can be carried out when the customer makes a settlement (interview with informant III).

Down-payment for purchase of goods is also recognized as receivables. When the customer cancels the purchase, the down-payment is returned after the costs incurred by the seller are 


\section{International Journal of Business Management and Economic Review}

Vol. 2, No. 06; 2019

ISSN: 2581-4664

calculated as stated in paragraph 30. However, $B S M$ does not record the down-payment because the purchase of goods is represented by the customer. In practice, down payment is held and paid by the customer to the supplier (interview with informant III).

\section{Presentation of Murābahah Transactions}

The interview results indicate that the presentation of murābahah transactions at $B S M$ is in accordance with PSAK Number: 102. However, this account has never been presented in financial statement transactions related to inventory of murābahah assets, owing to lack of the assets by the bank. In fact, inventory has a zero balance therefore, it is directly credited with the same amount when the bank recognizes the hand-over to customers (Yaya et al., 2009).

\section{Disclosure of Murābahah Transactions}

Based on disclosures made at Bank Syariah Mandiri, the bank seller does not disclose matters related to the murābahah transaction, such as: (a) the acquisition price of its assets and (b) if the appointment of orders in murābahah is included in the obligation.

\section{RESEARCH IMPLICATIONS}

This research creates a positive contribution to Islamic banks in Aceh Province, especially Bank Syariah Mandiri regarding the implementation of accounting murābahah. The study can be a reference to murābahah financing given to prospective customers therefore, it does not conflict with the provisions of Islamic principles.

Furthermore, itis a reference for further researchers to continue developingresearch in order to enrich the knowledge and understanding of Islamic finance.

\section{CONCLUSIONS, LIMITATIONS, AND SUGGESTIONS Conclusion}

Murābahah Accounting Transactions conducted by Bank Syariah Mandiri are not fully in accordance with PSAK Number: 102. This can be seen from the characteristics of its contract which states that the selling price of goods is equal to the acquisition price and profits which the must not be disclosedto the buyer. In fact, the BSM does not make a sale/purchase agreement such as those previously mentioned. However, the bank lends cash to customers' needs, who is in turn obliged to return the loan to the bank along with the agreed margin.

Alternatively, it is stated that murābahah assets are obtained for the purpose of resale using its contract. BSM has never owned assets. In addition, several transactions such as the purchase of ordered goods to suppliers, deductions related to acquired goods, sales of murābahah assets to customers, cannot be recorded by $B S M$. Besides that, $B S M$ recognizes murābahah benefits using the annuity method, with the financing benefits identified proportionally. Furthermore, BSM does not present financial transaction statement transactions related to inventory of murābahah assets owing to lack of profits. Assets always have a zero balance, because banks directly credits it with the required amount to identify its hand-over to customers.

\section{Limitation}

Some of the limitations in this study are, (1) access to murābahah financing transaction data collection at Bank Syariah Mandiri of Banda Aceh, (2) it is conducted based on a case study due 


\section{International Journal of Business Management and Economic Review}

Vol. 2, No. 06; 2019

ISSN: 2581-4664

to time constraints, 3) research data obtained from informants working in BSM, (4) the results of qualitative research with a case study approach cannot be generalized to different objects.

\section{Suggestion}

The researcher advised $B S M$ to apply PSAK Number: 102 with regards to accounting murābahah as a reference in its implementation, updating revisions by IAI and following DSN-MUI. Internal accountants at Bank Syariah Mandiri must understand this rule, to examine and assess the suitability and implementation of accounting murābahah with the applicable provisions. The Financial Services Authority $\{$ (Otoritas Jasa Keuangan (OJK) $\}$ as supervisor of Islamic Financial Institutions in Indonesia is expected to be able to give authority to Islamic banking institutions to own/provide assets in conducting murābahah financing transactions in accordance with $D S N$ MUI.

\section{REFERENCES}

Ash-Shiddieqy, H. (1997). Pengantar Fiqh Muamalah, Jakarta: Bulan Bintang.

Azkanar, O. (2016). The Effectiveness of Murabahah in Islamic Law in Terms of House Financing: Comparing the UK and Malaysia. Journal Law and Justice, 7(13), 130-167.

Bank Indonesia. (2013). Statistik Perbankan Syariah: September 2013. (Online), http://www.bi.go.id.

Buziek, S. (2011). The Practice Of Murabaha: A Comparative Study Between Bank Muamalat Indonesia and Albaraka Bank In South Africa. Skripsi. Jakarta: Fakultas Syariah dan Hukum Universitas Islam Negeri Syarif Hidayatullah.

Dewi. G., \& Wirdyaningsih. (2007). Hukum Perikatan Islam di Indonesia. Jakarta: Prenada Media.

Dewan Syari'ah Nasional-MUI, Himpunan Fatwa Dewan Syariah Nasional-Majelis Ulama Indonesia, No.04/DSNMUI/IV/2000, tentang Murabahah.

Dimyauddin, D. (2010). Pengantar Fiqih Muamalah. Yogyakarta: Pustaka Pelajar.

Habibah, M., \& Nikmah, A. (2016). Analisis Penerapan Akuntansi Syariah Berdasarkan PSAK 102 Pada Pembiayaan Murabahah Di BMT Se-Kabupaten Pati. Jurnal Ekonomi Syariah, 4(1), 114-136.

Hanum, Z. (2014). Analisis Penerapan Transaksi Murabahah Pada PT. Bank Pembiayaan Rakyat (BPR) Syariah Gebu Prima Medan. Jurnal Ilmu Ekonomi dan Studi Pembangunan, 14(1), 18-24.

Harahap, S. S. (2007). Teori Akuntansi, Jakarta: PT. Raja Grafindo Persada.

Hariyanto, H. (2015). Perlakuan Akuntansi Syariah PSAK No. 102 Pada BMT Ummah Banjarmasin. Jurnal Ilmiah Ilmu-Ilmu Keislaman Al-Banjiri, 4(2), 185-193.

Hasmitha, D., \& Ja'far, H. (2012). Analisis Penerapan dan Perlakuan Akuntansi Murabahah Untuk Pembiayaan Konsumtif Studi Kasus Pada PT. Bank Muamalat Indonesia Cabang Medan. Jurnal Ekonom, 15(2), 64-69.

Ikatan Akuntan Indonesia. (2013). Pernyataan Standar Akuntansi Keuangan No. 102 tentang Akuntansi Murabahah Jakarta: IAI

Imama, L.S. (2014). Konsep dan Implementasi Murabahah Pada Produk Pembiayaan Bank Syariah. Jurnal Iqtishadia, 1(2), 222-244.

Indriantoro, N., \& Supomo, B. (2002). Metodologi Penelitian Bisnis untuk Akuntansi dan 


\section{International Journal of Business Management and Economic Review}

Vol. 2, No. 06; 2019

ISSN: 2581-4664

Manajemen, Cet. Ke-II, Yogyakarta: BFEE UGM.

Kholis, N. (2007). Evaluation to the Practice of Murabahah in the Operations of Baitul Mal Wattamwil (BMT), Yogyakarta. Jurnal Ekonomi Islam, 1(1), 95-108.

Luayyi, S. (2015). Evaluasi Perlakuan Akuntansi Pembiayaan Murabahah Berdasarkan PSAK 102 Pada Koperasi Jasa Keuangan Syariah Ar-Rahmah Kabupaten Kediri. Jurnal Cendekia Akuntansi, 3(1), 111-120.

Maryanti, Y., Hidayat, A.R., \& Nurhayati, N. (2016). Analisis Penerapan PSAK 102 di BMT Itqan Dalam Kaitannya dengan Pembiayaan Murabahah. Jurnal Prosiding Keuangan dan Perbankan Syariah, 2(1), 103-108.

Menne, F., Idris, M., \& Erni. (2017). Murabahah Accounting In BNI Syariah Makassar. Jurnal Riset, 3(6), 18-31.

Muhammad, M. (2000). Sistem dan Prosedur Operasional Bank Syari'ah, Yogyakarta: UII Press.

Muhammad, M. (2002). Pengantar Akuntansi Syariah. Jakarta: Salemba Empat.

Nasir, S.M., \& Sululing, S. (2015). Penerapan Akuntansi Murabahah Terhadap Pembiayaan Kredit Pemilikan Rumah Pada Bank Syariah Mandiri Luwuk. Jurnal Akuntansi, 19(1), 110-127.

Rahmanti,V. N. (2013). Mengapa Perbankan Syariah Masih Disamakan dengan Perbankan Konvensional. Jurnal Ekonomi, Manajemen dan Akuntansi Islam IMANENSI, 4(1), 6268.

Rahmawati, D.I, Sambharakreshna, Y., \& Kusufi, M.S. (2009). Kesesuaian Perlakuan Akuntansi Pembiayaan Syariah dengan Standar Akuntansi Keuangan dan Islamic Values Studi Kasus Pada PT. Bank Syariah Mandiri Cabang Pamekasan. Jurnal Infestasi, 5(1), 32-44.

Rifqi, M. (2008). Akuntansi Keuangan Syariah Konsep dan Implementasi PSAK Syariah. Yogyakarta: P3EI Press.

Rusydi, M., \& Nasir, S.S. (2009). Perlakuan Akuntansi Murabahah Ditinjau Dari PSAK No.102 Pada PT. Bank Syariah Mandiri Cabang Makassar. Jurnal Ilmu Ekonomi Studi Pembangunan, 1(1), 17-29.

Sabiq, S. (1988). Fiqh Sunnah. Bandung: PT. Al-Ma'arif.

Siyoto, S., \& Sodik, M, A. (2015). Dasar Metodologi Penelitian. Yogyakarta: Literasi Media Publishing.

Wardi, J., \& Putri, G.E. (2011). Analisis Perlakuan Akuntansi Syariah Untuk Pembiayaan Murabahah, Mudharabah, serta Kesesuaiannya dengan PSAK No. 102, dan 105. Jurnal Pekbis, 3(1), 447-455.

Wulandari, P., Putri, N.I.S., \& Sulung, L.A. (2016). Contract Agreement Model for Murabahah Financing in Indonesia Islamic Banking. International Journal of Islamic and Middle Eastern Finance and Management, 9(2), 190-204.

Yaya, R., Martawireja, A.E., \& Abdurrahim, A. (2009). Akuntansi Perbankan Syariah: Teori dan Praktik Kontemporer. Jakarta: Salemba Empat.

Yusuf, M. (2013). Analisis Penerapan Pembiayaan Murabahah Berdasarkan Pesanan dan Tanpa Pesanan serta Kesesuaian dengan PSAK 102. Jurnal Binus Business, 4(1), 15-29. 